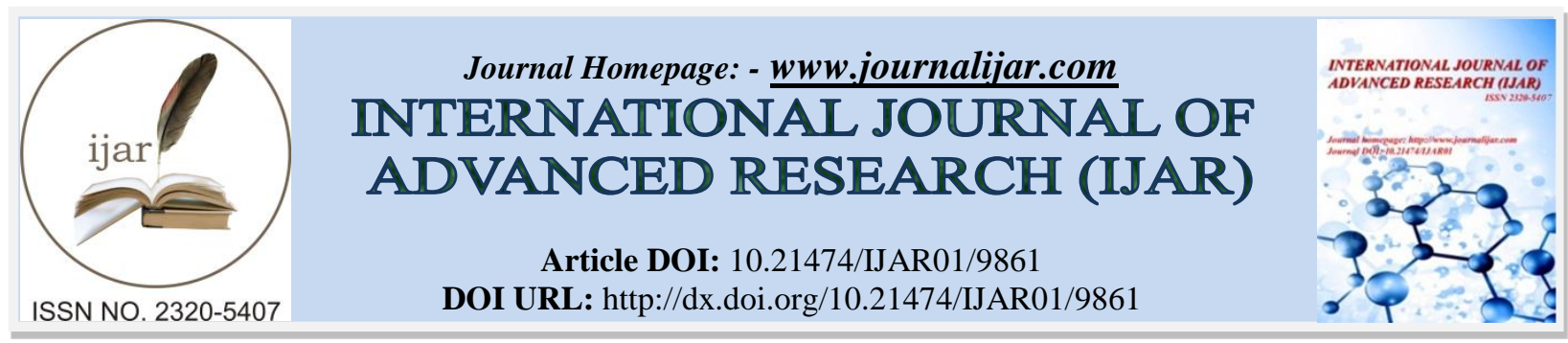

RESEARCH ARTICLE

\title{
UNDERSTANDING THE RELATIONSHIP BETWEEN CORPORATE SOCIAL RESPONSIBILITY AND FINANCIAL PERFORMANCE.
}

Ezatullah Najimi and Md. Abu Naim Shorkar.

School of Economics, Shanghai University, Shanghai, China.

\section{Manuscript Info}

\section{Manuscript History}

Received: 08 August 2019

Final Accepted: 10 September 2019

Published: October 2019

\section{Key words:-}

Corporate Social Responsibility (CSR), Corporate Financial Performance (CFP), Mari Petroleum Company Limited (MPCL), Karachi stock exchange (KSE), Lahore Stock exchange (LSE) and Islamabad Stock Exchange (ISE).

\begin{abstract}
The proclivity for writing this paper is to evaluate the association of the two variables; corporate social responsibility (CSR) and corporate financial performances (CFP) of Mari Petroleum Company Limited (MPCL), one of the largest oil \& gas exploration companies in Pakistan, listed in all three stock exchange of Pakistan: Karachi stock exchange (KSE), Lahore Stock exchange (LSE) and Islamabad Stock Exchange (ISE). Based on the annual reports of the (MPCL), the company appears to be more committed to its CSR activities for the wellbeing and welfare of the society, healthcare of employees, environment protection. To examine the relationship of CSR and CFP for the Mari Petroleum Company Limited, the secondary data has been extracted from the annual reports of each year published by the company for the period of six years from 2012-2017, annually. The variables for the analysis of the relationship included are: CSR, as an independent variable of the model; indicators used to measure CSR performance of the company are; sum of annual contribution and spending of MPCL on CSR activities in term of donation, salary, wages and benefits, social welfare, and CFP as independent variable of the model; indicators used to measure the financial performance of the company are: Net profit, Net Profit Margin and Total Asset of MPCL. Correlation and regression analysis of the log-log model has been used to figure out the association and the nature of the relationship between these two dependent and independent variables.
\end{abstract}

Copy Right, IJAR, 2019, All rights reserved.

\section{Introduction:-}

Socially responsible organizations should be ethical and sensitive to social, cultural and environmental issues. To initiate social responsibility or commitment to social responsibility will help individuals, organizations, and governments to have a positive influence on the progress, wellbeing, and welfare of society. The organizations are established based on the social and public needs, the purpose of the organizations is to provide the goods and services the community needs. So neither the organization can be separated from the community nor can the community be without organizations, so the consequences of this mutual relationship are that every decision of the organization can influence the community directly or indirectly. So as the decision of the organization can influence the community directly or indirectly, therefore, it will lead the community to expect their organization to share their performance and ask them to be accountable for that. Corporations as part of the community and citizens of the community have come to realize that they are created by society, they are part of the community they operate and do 
business for the community and take their laws from the community in which they operate. The roles, goals, objectives, and operation of the organization have to be following the full understanding of environmental and social impacts and responsibilities as their operations and decisions will have a direct or indirect influence on the environment, individual of community and the society and all other internal and external stakeholders. Therefore, the citizenship of companies in the development and wellbeing of communities is considered as a completer and more insignificant role of the organizations in society. The overall performance of the organization is dependent to social performance activities, for instance, social welfare, environmental protection, interest of all stakeholders and these activities will help the organization to develop an excellent and well know image in the society and therefore can achieve the confidence and trust of society that will led to the sustainability of the organization and long-run development of the company as well as the achieving other financial goals. CSR activities of an organization include the responsibility of the organization towards both internal and external stakeholders especially the consumers, customers, employees, shareholders in addition to profit maximization. The activities include social wellbeing, good working environment and health care for the employees, donation and environment protection.

As the term, CSR has been increasingly globalized over a few decades and attracted the attention of the scholars and researchers over the globe academically and professionally. The term CSR is now a widely- known and globally established term as most of the large organization and some small organization works to be highly committed to CSR activities and to be more socially responsible. In the past, more other similar terms have been used, still being practice instead of CSR, for instance, corporate citizenship, socially responsible investment, and so on. Still, there are diverse definitions of CSR but with being no universal consensus. And this lack of worldwide agreement and universally diverse understanding and the increasing globalization of the term CSR led the scholars and researchers to study CSR and to find out how the organizations and governments and the stakeholders define CSR and to know their understanding of CSR. Most of the studies have been focused to evaluate and to know the understanding of the different large companies in the USA, Canada, UK; but few of them have tried to figure out the distinction of definition among countries (Hopkins, 2004). Corporate social responsibility has been conceptualized deferentially by the governments of many countries, corporations, community citizens, and stakeholders, and have a different understanding of the word CSR, there is no universally prevailing definition of CSR that could be oriented around the globe.

CSR has been defined by several scholars; generally, it is concern with relationship of corporation with both the internal and external stakeholders, the governments of the region where the corporations operate, individuals of the community, consumers, customers, and other stakeholders; the corporations may interact with these sectors directly or indirectly and might affect their transactions directly or indirectly. As stated, before that CSR has been defined by numerous scholars and large corporations variously. (Abagail McWilliams, Donald Siegel, 2001) Define CSR as "actions that appear to further some social good, beyond the interests of the firm and that which is required by law," (p. 17). The CSR has been defined by European Union as "a concept whereby companies integrate social and environmental concerns in their business operations and their interactions with their stakeholders on a voluntary basis" (European Commission, 2002), (Alexander Dahlsrud, 2006), has conducted a research about the analyses of thirty seven definition of CSR to evaluate the definitions of CSR and the analysis shows, the existing definitions are compatible to large percentage and he concluded that the confusion is not due to how CSR is defined, however, is about "how CSR is socially constructed in a specific context". The primary objective of an organization is to maximize its profitability. From the business point of view, the aim of CSR activities appears to be the way of obtaining competitive superiority in the market, not merely it should be the case, though the commitment to CSR also improves the sustainability of an organization and help the long-run development of the organization. The impact of investing in corporate social responsibility will ascertain the attempts and consideration of investing in social activities.

If the influence of investing in social activities is positive which will contribute to increasing the profit, the organization will invest more in the CSR to increase profitability and to have a better financial performance. If the investment on social activities persuade negative effect on financial performance or will just lead to cost maximization, then the organization will be prudent regarding CSR activities and would not like to invest more and to contribute more on CR activities. Hence for the improvement of CSR implementation, it is of great significance for both the government and private sectors to analyze the relationship of corporate social responsibility and corporate financial performance. Most of the large companies and some small companies at present companies state their CSR performances and their contribution to CSR activities in the financial statement and annual reports of the company and some companies also publicize their annual CSR report to show their commitment and engagement in 
different aspects of CSR activities. And those companies that state their CSR contribution in their annual report will receive a better reaction from the community. The CSR performance disclosure helps to gain the public trust and confidence regarding the safety and health of the consumers by using the products of the company and to let the consumers and all other stakeholders know that the company has a responsible and ethical operations of the production and the company is thoroughly committed to the well-being and welfare of the citizens of the community, the protection of the environment. Besides gaining public trust and confidence the sales of the company will be increased and will be led to higher profitability and therefore will help in the sustainable and long-run development of the company. The MPCL discloses their annual CSR performance in their annual reports which shows the strong commitment of the company in CSR activities, social welfare, employees' health care, and environment protection.

The purpose of writing this paper is to evaluate the relationship of CSR activities and the financial performance and its effect on financial performances of Mari Petroleum Company Limited (MPCL), one of the largest oil and Gas Exploration Company of Pakistan and major Gas reservoir, listed in all three stock exchange markets of Pakistan. MPCL is the largest producer of natural gas having 11 percent market share. The MPCL appears to be highly committed to its social responsibility by commitment and engagement to the welfare of society, healthcare of employees. Based on the annual report of MPCL, the company contributes a large amount of it is on CSR activities annually and donates a huge amount for the support of society, social wellbeing and health care of the employee and the local community. This paper will focus on how the commitment of the company influences the financial performance of the company.

Corporate Social Responsibility at Mari Petroleum Company Ltd.

Companies today are asked by the shareholders and other stakeholders not only to focus on the maximization of their profitability but also consider the social and community problems, regarding the wellbeing and economic improvement of the community, protection of the environment. Therefore, the stakeholders (which mainly include, shareholders, employees, consumers, customers, suppliers, society, government) wishing the organizations to understand their responsibility concerning the solution of the above problems and want the organizations to be responsible for. In order the companies to share and present their contribution and their commitment consider to addressing the economic, social and environmental problems (refer to CSR issues), the companies are publicizing their CSR information by their CSR reports. Different CSR report formats have been used by the companies; companies also used the Global Reporting Initiative (GRI) G4 Guidelines to provide the CSR report.

The CSR report contains different CSR elements that present the company's engagement and the contribution of the company towards the CSR activities. Mainly the CSR reports include the element like the CSR strategy of the company, the CSR vision, and mission of the company, CSR executive and stuff, the most significant element of the report is disclosures issues of the main stakeholders for example Shareholders responsibility, Employees, Customers, Suppliers, Communities, Governments, and Regulators. The Mari petroleum company ltd. Disclose their annual CSR report. MPCL CSR report elements mainly represent the commitment of the company on the communities' responsibility in the area of education, by providing funds for the construction, renovation, and maintenance of various schools in the area where the company operates and providing scholarships for the students. In the area of health care, for the company to make sure the locals of the community of the operating area of the company have the availability of the advantageous medical services. Therefore, the company is allocating funds for building and maintain the medical institutions, Medical Camps by conducting major healthcare projects to provide healthcare facilities to the individuals of the community. Providing safe, clean and drinking water to the locals of the community by water supply schemes for the wellbeing and healthcare of the individuals of the community. Providing donations, financial and technical assistance to the people affected by the natural disaster.

MPCL as a part of their social responsibility also provides sponsorship for the sports players. The company has launched a new project of "Youth in Sports" sponsorship program to motivate young male and female sports players (Mari Petroleum company ltd. Annual Report, 2017). Based on MPCL annual reports, the company mainly focus the community responsibility and employees' responsibility as CSR stakeholders, therefore, this research paper will also evaluate the CSR performance of the company based on the contribution and engagement of the company in community and employee responsibility as corporate social responsibility stakeholders. 


\section{Literature Review}

At present the corporations are being encouraged and enforced by the stakeholders to invest and enhance their contribution on the corporate social responsibility, subsequently some of the firms responded by making more investment and engaging to a greater extent on corporate social responsibility, however some of the corporations still believe that investing in corporate social responsibility will not be led to the maximization of their profits except cost maximization. This contradictory results and inconsistency, as well as the lack of global consensus on the understanding of CSR, led researchers and scholars to examine the relationship between CSR and Corporate financial performances to figure out the relationship between and effect of the CSR performances on financial performances and its nature. Several studies have been made to examine the relationship between corporate social responsibility and corporate financial performances. Contradictory results have been presented. Most of the studies reported a positive relationship between CSR and financial performance and some of the researchers also claim the negative relationship between these two variables and as well as no relationship has also been emanated. As every paper has its limitations, therefore, causes behind such contradictory results appear to be the existence of several limitations through which results and findings of the studies have been affected and varied results have been connoted. One of these limitations for finding the relationship of these two variables appears to be applying various mis specified regression models by the researchers, in which several significant explanatory variables or even control variables have been excluded which seems to be significant in the model and can have considerable significant relationship and so the omitting of those variables can certainly affect the results. The possible reasons behind the above three contradictory conclusions of the studies for CSR and CFP associations evaluation will be explained below:

(Abagail Mcwilliams And Donald Siegel, 2000), Mainly there are two types of studies, investigating the association of financial performance and social responsibility, one types of studies uses the event study methodology to evaluate the short-run financial performance and the involvement and commitment of the company in CSR activities, and this type of studies concluded different results, some studies connoted positive relationship and some of the studies presented negative relationship; similarly the other types of studies indicated contradictory results of studying the relationship of short-run financial performance and CSR activities performance. Several studies have also been conducted, consequently, no direct relationship between CSR and CFP has been reported. (Jordi Surroca, Josep A. Tribo, and Sandar Waddock, 2010), have examined the effects of the firm's intangible resources in mediating the relationship between corporate social responsibility and financial performance. They reported that there is no direct relationship between corporate social responsibility and financial performance. But there is only an indirect relationship that relies on the mediating effect of a firm's intangible resources. Positive results between CSR and CFP have also been presented, (Abagail Mcwilliams And Donald Siegel, 2000), studies result indicates positive relationship between financial performance and social responsibility, by including the $R \& D$ variable which appears to be the most essential determinant of financial performances and which has been excluded by the other studies which can significantly influence the results. Multiple studies have been made to find out the nature of the relationship between CSR and Financial performance but few studies have been conducted to find out the relationship between CSR and the age of assets. (Philip L. Cochran and Robert A. Wood, 1984) says that one of the financial performance proxies is the age of assets which has significant strong positive correlation with CSR performance and if this independent variable is omitted from the regression model then it will result from bogus relationship of CSR and financial performances, the results indicate that organization with new and updated assets will have higher CSR performances and organization with old and depreciated assets will have low CSR performance. (Li Sun, 2012) Extended the (Philip L. Cochran and Robert A. Wood, 1984) studies to examine the relationship between CSR and financial performance.

He has reported two findings, first positive relationships between CSR and financial performance. Second, a strong correlation between the age of assets of the company and CSR performance. This represents that corporation which has younger assets shows higher CSR performance as compare to the one which has older assets. He suggested that future studies of CSR need to have the age of asset variable as their control variable in the regression model. (Kenneth E. Aupperle and Deane Van Pham, 1989), studied the relationship between CSR and financial performance through long-term financial measures and reported no relationship between CSR and financial performance. (Zhiyu Cui, Xiaoya Liang, and Xiongwen Lu, 2013) Evaluated the relationship of CSR and average sales growth rates by using the sample data of private firms in china; a negative relationship of commitment and engagement to CSR activities and the average sales growth rate has been shown. Studies have also been conducted to find out the relationship between CSR and economic performance. (Peter Arlow and Martin J. Gannon, 1982), no evidence has been provided to show a positive relationship between CSR performance and economic performance. 
(Edward Nelling \& Elizabeth Webb, 2008), by studying the relationship between the CSR and financial performance, emanated the result of an existing relationship between these two variables by using traditional statistical techniques. And a weaker relationship has been shown between these variables by using a time series fixed-effects approach. Studies have also been conducted to figure out the nature of the relationship between CSR and intangible resources. (Surroca, Josep A. Tribo, Sandra Waddock, 2010), found no direct relationship between corporate social responsibility and corporate financial performance but an indirect relation between intangible resources and corporate social responsibility.

Most of the CSR stakeholders will have a direct negative or positive influence on the financial performance of the company and some will have an indirect impact on financial performance. (Xiping Pan, Jinghua Sha, Hongliang Zhang, and Wenlan Ke, 2014), studied the influence of the different CSR stakeholders on the financial performance of the company; shareholder responsibility, employee responsibility environmental responsibility, supplier, customer and consumer responsibility that have a direct influence on the operations of the firm have significant relationships with CFP, however public responsibility does not show significant interaction with CFP. The shareholder has a positive effect on the CFP, supplier, customer, consumer responsibility and environmental responsibility which increases the cost of production will have negative effects on CFP. (Chin-Shien Lin, Ruei-Yuan Chang and Van That Dang, 2015), Have been concluded the study by indicating that the variable intellectual capital serves as the mediator in the relationship between corporate social responsibility and financial performance, and the direct impact of the CSR activities on financial performance is moderated by the type of industry. (Leonard A. Jackson, Nan Hua, 2009), showed a positive relationship between financial performance and CSR of those lodging and gaming firms that have high ranking positions based on their CSR performance and commitment. (M. Victoria López, Arminda Garcia, and Lazaro Rodriguez, 2007) By investigating the relationship of CSR and CFP, negative result between this two-variable has been reported by using the accounting measure of net profit for the measurement of the financial performance of sampled firms, and to evaluate the CSR performance the researcher used Dow Jones Sustainability index; industry, size, and risk are considered as control variables.

The study only focused on the short-term financial performances and CSR which represents the limitation of the study, therefore concluding the negative impact of CSR activities on financial performances at the beginning of the engagement in CSR practices. And further researches are suggested to be conducted and to consider the long-run financial performances. (Friedman, Milton, 1970), says that there is a negative association between CSR and CFP in his article "The Social Responsibility of Business is to Increase Its Profits", published 35 years ago on New York Times magazine. Friedman rejected the mostly believed thinking that organizations have social responsibility. Corporations as a legal person cannot have social responsibility rather the managers are responsible and should manage the business to maximize the profitability of the organization.

\section{Hypothesis}

Based on the literature review, different indicators have been used for the measurement of CSR and CFP to evaluate the relationship between these two variables, contradictory; positive, negative, direct and indirect relationship results have been presented regarding the association of these variables. In this paper, I hypothesize the positive correlation between CSR and the financial indicators of MPCL.

1. H1: Positive correlation between CSR and Net Profit of (MPCL)

2. H2: Positive correlation between CSR and Total Assets of (MPCL).

3. H3: Positive correlation between CSR and Net Profit Margin of (MPCL)

\section{Research Methodology:- \\ Data}

The tendency of writing this paper is to examine the relationship between CSR and CFP (MPCL), therefore this research paper is having a correlational nature. To find out the nature of the relationship of these variables, the time series data has been extracted from the annual reports and financial statements of the MPCL for the period of six years from 2012-2017. The data has been analysed based on the correlation and generalized least square regression, using the MS Excel and Stata software to figure out the association of these variables. Generally, the two variables have been used are CSR and CFP and methods of evaluating these two variables are explained below: 


\section{Measuring Financial Performance}

Mainly two bases have been undertaken to measure financial performance by scholars. Accounting based and market-based measures; both have been universally recognized as a reliable and accurate index of corporation's financial performance, cited by (Gentry, Richard J.; Shen, Wei) both measures evaluate the different perspectives of financial performance. The accounting-based measurement evaluates the financial performance of an organization by using the indicators: Return on Assets (ROA), Return on Equity (ROE) and Return on a share (ROS)... the market-based measurements are Tobin'Q and market value which can be calculated based on market value to represent the evaluations of an organization by an investor. As compared to the market base measure the accountingbased measure represents the internal decision-making process of an organization and the performance of the managers cited by (Chin-Shien Lin, Ruei-Yuan Chang, and Van That Dang, 2015). Most of the prior studies have used accounting-based measurements to evaluate the financial performance of the companies.

Parallel to the most prior studies (Samra Kiran, Shahid Jan Kakakhel and Farzana Shaheen, 2015), we will apply the accounting base measure of CFP to evaluate the financial performance of MPCL; and for the measurement of financial performance of MPCL we will use the net profit (profit after taxation), net profit margin to sale; is calculated by the dividing of net profit by sale, and total assets. So, the independent variables used in the paper are Net profit, profit margin and total asset of MPCL.

\section{Measuring CSR Performance}

The SCR has been significantly improved through the decades and now it's perceived as a very important phenomenon. As we stated earlier, there is no universally consistent definition of CSR, several scholars and governments defined CSR variously, there is also no globally adopted and solid evaluation of CSR performance, so divergent procedure have been used by scholars and researchers to evaluate the CSR performance. Scholars used data collected by their own conducted survey and questionnaires answered by the top-level management of the organization to evaluate the CSR performance. Most researchers used KLD's index for CSR performance. KLD is the most applied index for the evaluation of CSR performance which evaluates the different aspects and both internal and external stakeholder performances. KLD index was changed to the MSCI ESG (Environmental, Social, and Governance) after the ownership of the KLD has been sold out to MSCI Inc. The evaluation of CSR performance is a complicated structure, as it is consisting of both internal and external factors, so both of the external and internal factors should be considered while evaluating the CSR performance. Most researchers and scholars had used their procedure for evaluating the CSR for various industries. HEXUN has also been used as an SCR performance data provider.

The financial website evaluates the CSR performance of all firms operating in China. HEXUN financial website evaluates the CSR performance of all chine's firms based on five aspects which include both the external stakeholder's responsibility and internal stakeholders' responsibilities; internal stakeholders' responsibilities are the responsibility of shareholders and responsibility of employees. The external stakeholders' responsibilities are the consumer's responsibility, customer responsibility, environmental responsibility, and social responsibility. Responsibility of all factors consists of different sub aspects; the shareholder responsibility is to take care of the profitability of the organization's debt and credit condition and so on... Employee responsibility involves health care, working environment, of employees. Environmental responsibility includes the increased in the percentage of usage of clean energy, a decrease in usage of water, avoiding carbon production which causes damage to the environment. The public responsibility covers the contribution of the organization in donations, welfare activities, and taxes. In this research paper, I could only evaluate the contribution of MPCL toward the employee responsibility and social responsibility aspects of CSR. So, I evaluate the CSR of the MPCL as the sum of donations and salaries, wages, benefits and welfare activities contributed by the company during the six years of evaluation.

\section{Model Specification}

Multiple Regression analysis is the process of estimating the relationship of one dependent variable with more than one independent variable. The purpose of this paper is to examine the relationship between CSR as the dependent variable and indicators of CFP as independent variables. Therefor multiple regression model is used to figure out the association between social performance and financial performance of MPCL. In this research paper, the $\log -\log$ form of multiple regression models has been used due to large figures of variables in the data and correlation regression analysis has been applied to figure out the association of the variables. 


\section{Results, Analysis and Interpretation: -}

Table 1:-correlation between CSR, total asset, net profit and net profit margin.

\begin{tabular}{l|r|r|r|r|}
\hline & \multicolumn{1}{|c|}{ CSR } & \multicolumn{1}{|c|}{ TA } & NETPRO & NETPROMAR \\
\hline CSR & 1 & & & \\
\hline TA & 0.954722 & 1 & & \\
\hline NETPRO & 0.99241 & 0.963775 & 1 & \\
\hline NETPROM & 0.986804 & 0.977941 & 0.989592 & 1 \\
\hline
\end{tabular}

Table 1, this table represents the result of the correlation between the CSR performance and financial performance indicators of MPCL. Determinant: total assets, net profit, net profit margin is used as independent variables to indicate the financial performance of MPCL, and CSR is used as an independent variable which shows the contribution of the company in CSR activities. The results show a strong positive correlation between financial performance determinant (total assets, net profit, and net profit margin) and CSR.

Table 2:-Regression resultsLCSR (dependent variable), LTA (independent variable)

\begin{tabular}{|c|c|c|c|c|c|c|c|}
\hline Source & ss & df & & MS & & \multirow{3}{*}{$\begin{array}{l}\text { Number of obs }= \\
\text { F( 1, } 4)= \\
\text { Prob > }\end{array}$} & $=$ \\
\hline Mode1 & & 1 & & & & & 041 \\
\hline Modiduat & . & 1 & & דת & & & 0.0041 \\
\hline Residual & .013109708 & 4 & .003 & 277427 & & R-squared & $=0.8973$ \\
\hline Total & .127683361 & 5 & .025 & 536672 & & $\begin{array}{l}\text { Adj R-squared } \\
\text { Root MSE }\end{array}$ & .05725 \\
\hline $1 \operatorname{csr}$ & Coef. & Std. & Err. & t & $P>|t|$ & [95\& Conf. & Interval] \\
\hline Ita & .8653601 & .1463 & 595 & 5.91 & 0.004 & .4590009 & 1. 271719 \\
\hline _cons & -3.2709 & 1.131 & 601 & -2.89 & 0.045 & -6.412727 & -.1290735 \\
\hline
\end{tabular}

Table 2, the results in table 2 show significant correlation between Log of CSR and Log of Total Assets, the coefficient of $\log$ of total asset is 0.86 and the p-value is 0.004 which is significant as 5\% level, and it shows that if the assets are increased by one percent the expected value of CSR will be increased 86 percent. The R-Squared value is 0.89 which shows that 89 percent variation in this model is caused by the total asset.

Table 3:-Regression resultLog of CSR (independent variable), Log of net profit (dependent variable)

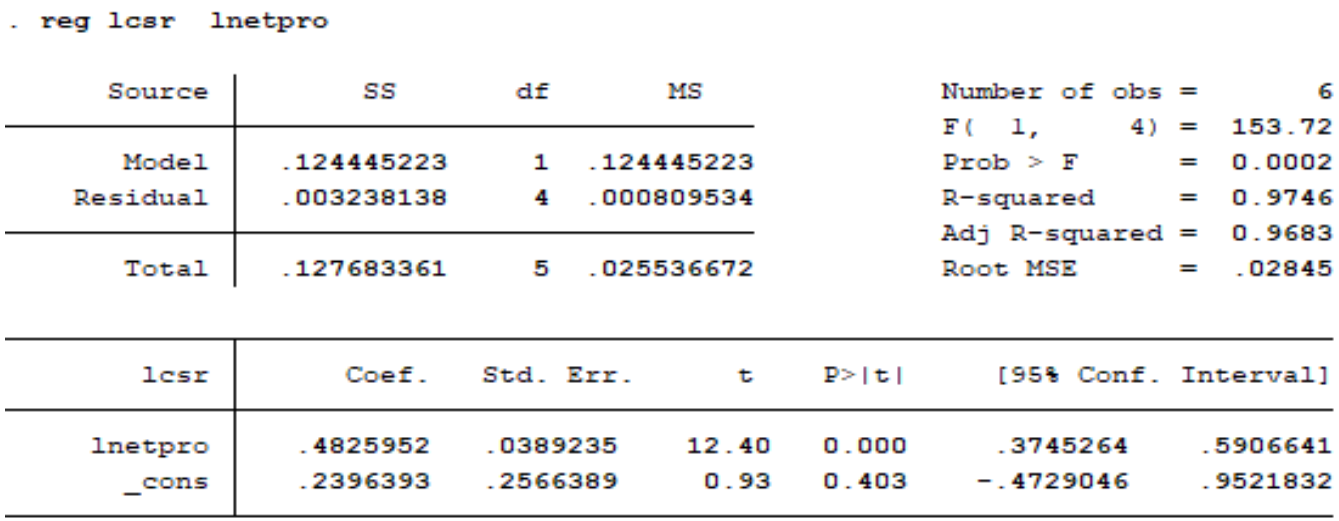


Table 3 represents the relationship between CSR and net profit. The log model shows a strong significant relationship between CSR and net profit, as the coefficient of net profit is 0.48 which shows that with a one percent increase in the net profit the CSR will be increased by 48 percent. The p-values show a significant correlation at any level between CSR and net profit.

Table 4: -Regression resultLog of CSR (dependent variable), Log of net profit margin (independent variable)

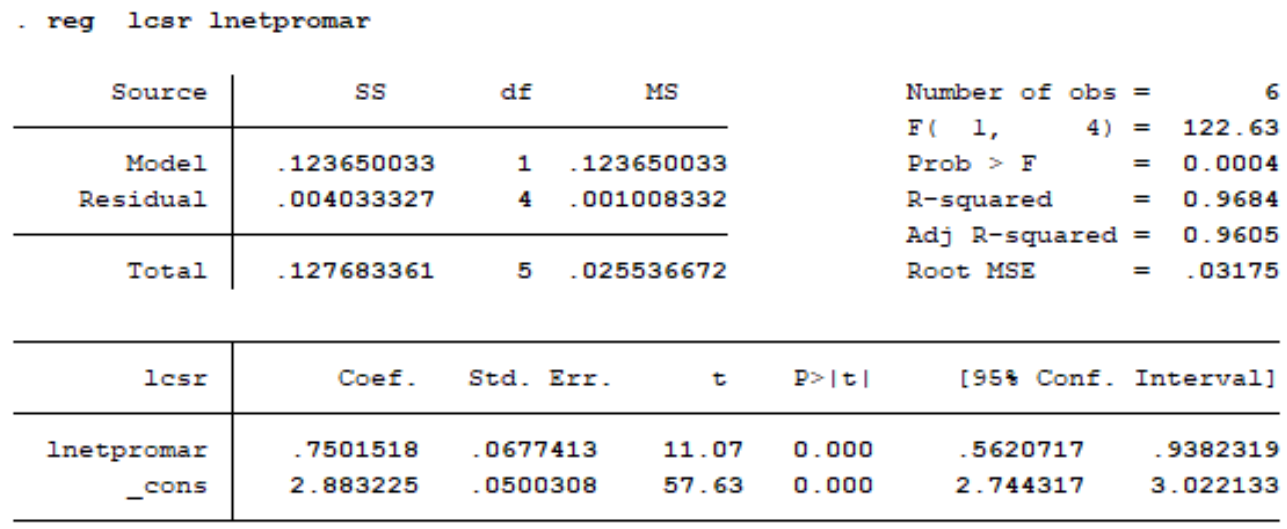

Table 4 represents the association of the log model between the dependent variable CSR and the independent variable net profit margin. The coefficient of net profit margin and the p-value show a significant correlation between CSR and net profit margin; the coefficient .75 shows that with a one percent increase in net profit margin the CSR is expected to increase by 75 percent. The p-value shows the two variables are significantly correlated at any level. In this log model, the R-Squared shows that the 96 percent variation in CSR is the cause of the net profit margin.

\section{Findings: -}

Based on the correlation and regression analysis of the secondary data of MPCL for six years, the results indicate the significant positive correlation between the dependent variable CSR and independent variable CFP indicators. It represents that as the values of net profit, total assets or net profit margin are increased, the SCR value will be increased significantly which connotes the more contribution toward CSR activities helps to build public confidence and trust. So, achieving the public trust develop the sustainability of the company and led to long-run development of the company and also helps to gain more other financial objectives.

\section{Conclusion:-}

In order to figure out the social corporate responsibility of Mari Petroleum Company Limited (MPCL); one of the largest oil \& gas exploration companies in Pakistan MPCL and its corporate financial performance, I had calculated the secondary data from the annual reports of the company regarding the financial performance and annual contribution on CSR activities for the period of six years. So to find out the association between the two variable, CSR and CFP; the CSR of the company is measured as the sum of the contribution of the company for donation, salaries, wage benefits, and social welfare during the six years; for the measurement of CFP the net profit, total assets, and net profit margin were considered as the CFP proxies. Correlation and regression analysis were conducted in MS excel and Stata. The results of the analysis show significant positive correlation between CSR with total Asset, net profit and profit margin separately, it represents that if the financial performance of the company is increased, the company will contribute more to the CSR activities for the growth and welfare of society and for healthcare of their employees which will result to gain public trust and will lead to the increase of the sales, consequently the profitability of the company will be increased. Therefore, all three hypotheses are accepted based on the correlation and regression analysis.

This paper has certain limitations, first it could not evaluate the commitment of the organization on overall main aspects of corporate social responsibly, as it only considers the employee's responsibility and social responsibility aspect of CSR for the company due to the significant challenge for conducting this paper which was finding CSR relevant data of the company regarding other aspects of CSR, as the environmental responsibility. Second, it does 
not include the effect of control variables which can have to affect the SCR performance. Further research can be conducted on more other large oil exploring companies that currently operate in Pakistan and all aspects of CSR can be evaluated, to find out the exact and more accurate association of oil exploring companies' CSR performance and financial performance. As the awareness of corporate social responsibility is significantly being increased universally, the Mari Petroleum Company needs to consider and pay more attention to their social responsibility in all internal and external stakeholders.

\section{Conflicts of Interest:}

The authors are contributed equally and declares no conflict of interest.

\section{References:-}

1. AbagaiL Mcwilliams And Donald Siegel. (2000). Corporate Social Responsibility And Financial

2. Performance: Correlation or Misspecification? Strategic Management Journal, 603-609.

3. Abagail McWilliams, Donald Siegel. (2001). Corporate Social Responsibility: A Theory of the

4. Firm Perspective. The Academy of Management Review, 117-127.

5. Alexander Dahlsrud. (2006). How corporate social responsibility is defined: an analysis of 37 definitions. Corporate Social Responsibility and Environmental Management, 1-13.

6. Chin-Shien Lin, Ruei-Yuan Chang and Van Thac Dang. (2015). An Integrated Model to Explain How Corporate Social Responsibility Affects Corporate Financial Performance. Sustainability, 8292-8311.

7. Edward Nelling \& Elizabeth Webb. (2008). Corporate Social Responsibility and Financial Performance: the "virtuous circle"' revisited. Springer Science+Business Media, 197-209.

8. European Commission. (2002). Corporate Social Responsibility: A Business Contribution to Sustainable Development. Luxembourg: Office for Official Publications of the European Communities.

9. Friedman, Milton. (1970). The Social Responsibility of Business Is to Increase Its Profits. New York Times, Gentry, Richard J.; Shen, Wei. (n.d.). The Relationship between Accounting and Market Measures of Firm Financial Performance: How Strong Is It? Journal of Managerial Issues.

10. Hopkins, M. (2004). Corporate social responsibility around the world. In M. Hopkins.

11. Jordi Surroca, Josep A. Tribo and Sandar Waddock. (2010). Corporate Reponsibility and Financial Corporate Responsibility. Strategic Management Journal, 463-490.

12. Kenneth E. Aupperle and Deane Van Pham. (1989). An Expanded Investigation into the Relationship of Corporate Social Responsibility and Financial Performance. Employee Responsibilities and Rights Journal.

13. Leonard A. Jackson, Nan Hua. (2009). Corporate Social Responsibility and Financial Performance: A Snapshot from the Lodging and Gaming Industries. The Professional Refereed Journal of the Association of Hospitality Financial Management Educators.

14. Li Sun. (2012). Further evidence on the association between corporate social responsibility and financial performance. International Journal of Law and Management, 472-484.

15. M. Victoria López, Arminda Garcia and Lazaro Rodriguez. (2007). Sustainable Development and Corporate Performance: A Study Based on the Dow Jones Sustainability Index. Springer, 285-300.

16. Mari Petrolium company limited. (2017). Annual Report. Pakistan: Mari Petrolium company limited.

17. Peter Arlow and Martin J. Gannon. (1982). Social Responsiveness, Corporate Structure and Economic Performance. The Academy of Management Review, 235-241.

18. Philip L. Cochran and Robert A. Wood. (1984). Corporate Social Responsibility and Financial Performance. The Academy of Management Journal, 42-56.

19. Samra Kiran, Shahid Jan Kakakhel and Farzana Shaheen. (2015). Corporate Social Responsibility and Firmprofitability: A Case Of Oil And Gas Sector Of Pakistan. City University Research Journal, 05.

20. Surroca, Josep A. Tribo, Sandra Waddock. (2010). Corporate Responsibility and Financial Corporate Responsibility. Strategic Management Journal, 463-490.

21. Xiping Pan, Jinghua Sha, Hongliang Zhang and Wenlan Ke. (2014). Relationship between Corporate Social Responsibility and Financial Performance in the Mineral Industry: Evidence from Chinese Mineral Firms. Sustainability, 4077-4101.

22. Zhiyu Cui, Xiaoya Liang, and Xiongwen Lu. (2013). Prize or Price? Corporate Social Responsibility Commitment and Sales Performance in the Chinese Private Sector. Management and Organization Reveiw. 